\title{
PENGARUH HARGA DAN CITRA MEREK TERHADAP KEPUTUSAN PEMBELIAN TIKET MASKAPAI CITILINK OLEH WISATAWAN NUSANTARA DI BANDARA NGURAH RAI, BALI
}

\author{
I Gede Cahaya Adi Putra \\ I GPB. Sasrawan Mananda \\ Ni Gusti Ayu Susrami Dewi \\ Email : cahayagede@gmail.com \\ PS. S1 Industri Perjalanan Wisata \\ Fakultas Pariwisata UNUD
}

\begin{abstract}
Citilink airlines is one of LCC ( Low Cost Carrier) flight in Indonesia, under management of Garuda Indonesia and established in 2001. The purpose of this research is to find out the influence of prices and brand images partial and simultaneous with domestic tourits decision to purchase the ticket and the location of this research at Ngurah Rai Airport, Bali. The sample technique used is purposive sampling and techniques of the collected sample were used with accidental sampling. The number of respondents used in this research are 150 of respondents. Analysis data used was validity test, reliability, assumption classical test, multiple regression analysis, analysis of koefisien determination, and Likert scale

The results of research is that the price of $(x 1)$ has positive effects and significant of decision of $(y)$ as Citilink ticket, with a significance value af 0,000 which is less than $\alpha=0.05$ and $t_{\text {count }}$ of 4,805 is larger than table 1,655. Brand images variables (x2) has some positive effects and significant of the decision of the purchase of ( $y$ ) Citilink ticket, with a significance value at 0,000 which is less than $\alpha=0.05$ and $t_{\text {count }}$ of 6,750 is larger than $t_{\text {table }} 1,655$. Variable of prices $(x 1)$ and brand images ( $x 2$ ) has some positive effects and significant of the decision of the purchase of ( $y$ ) Citilink ticket, with a significance value 0,000 which is less than $\alpha=0.05$ and $f_{\text {count }}$ of 115,605 larger than $f_{\text {table }} 3,06$.
\end{abstract}

Keywords: Price, Brand Image, Purchasing Decision, Ticket, Airlines.

\section{PENDAHULUAN}

Transportasi udara merupakan salah satu transportasi yang sangat dibutuhkan oleh wisatawan. Adapun kelebihan yang dimiliki oleh transportasi udara meliputi segi waktu dan harga, dimana waktu yang ditempuh dengan transportasi udara lebih singkat dan harga yang diberikan sesuai dengan apa yang didapat, sehingga wisatawan baik Mancanegara maupun Nusantara lebih berminat untuk menggunakan transportasi udara untuk menempuh perjalanan jauh.

Maka dari itu telah banyak bermunculan perusahaan penerbangan khususnya yang melayani rute penerbangan domestik yang menawarkan berbagai keunggulan keunggulan yang dimiliki oleh perusahaan tersebut. Di Indonesia memiliki dua jenis penerbangan yaitu : pertama, penerbangan yang menerapkan sistem full service dan kedua, sistem penerbangan bertarif rendah atau biasa disebut low cost carrier. Maskapai Citilink adalah sebuah maskapai penerbangan anak perusahaan Garuda Indonesia dan salah satu maskapai penerbangan $L C C$. Perusahaan ini berdiri tahun 2001. Citilink sempat menghentikan operasinya sejak 15 Januari 2008 diakibatkan beberapa isu buruk yang menimpa maskapai Citilink. Pada Agustus 2008 Citilink kembali beroperasi dan melanjutkan penerbangan pertamanya pada bulan September 2008. Pada tahun 2011 
maskapai Citilink melakukan rebranding dari segi nama, simbol, logo, dan warna.

Sebagai salah satu maskapai $L C C$ di Indonesia, Citilink cukup mampu bersaing dengan maskapai LCC lainnya. Hal ini dibuktikan dengan jumlah penumpang yang terus meningkat setiap tahunnya. Walaupun demikian jumlah penumpang tersebut pada tahun terakhir masih dibawah pesaingnya yaitu maskapai Lion Air, dimana maskapai ini mengangkut penumpang hingga 26.0000.000 penumpang. Dengan demikian maskapai Citilink harus memiliki strategi pemasaran atau gebrakan baru dilihat dari faktor - faktor yang dapat mempengaruhi wisatawan dalam mengambil keputusan pembelian tiket.

Keputusan pembelian merupakan tahap dalam proses pengambilan keputusan pembelian sampai konsumen benar benar membeli produk atau jasa (Sangadji, 2013). Ada berbagai macam faktor - faktor yang dapat menjadi sebuah pertimbangan wisatawan untuk mengambil keputusan. Salah satu faktor tersebut dapat dari faktor harga dan citra merek. Harga yang ditawarkan setiap maskapai memiliki harga yang berbeda beda sesuai dengan pelayanan maskapainya. Dari segi citra merek, setiap maskapai memiliki merek tersendiri sesuai dengan visi dan misi setiap maskapai. Citra merek ini dilihat dari segi warna, simbol, nama, slogan dan sebagainya yang dapat dan mudah diingat dibenak wisatawan (Kotler \& Amstrong 2006).

Dari pemaparan diatas terdapat berbagai macam faktor yang dapat mempengaruhi wisatawan dalam mengambil suatu keputusan, baik dari faktor harga maupun citra merek. Adapun penelitian yang dimaksud adalah untuk mengetahui pengaruh harga dan citra merek baik secara parsial maupun simultan terhadap keputusan pembelian tiket maskapai Citilink.

\section{METODE PENELITIAN}

Lokasi yang digunakan peneliti adalah di Bandara Internasional I Gusti Ngurah Rai, Bali. Tepatnya di terminal keberangakatan dan kedatangan domestik dan konter tiket. Jenis data yang digunakan dalam penelitian ini adalah data kuantitatif dan data kualitatif. Sumber data yang digunakan dalam penelitian ini adalah data primer dan data sekunder. Teknik pengumpulan data yang digunakan dalam penelitian ini adalah observasi, studi kepustakaan, teknik kuisioner dan teknik dokumentasi. Teknik penentuan sampel dilakukan dengan Purposive Sampling dan pengambilan sampel menggunakan accidental. Kriteria sampel dalam penelitian ini adalah wisatawan Nusantara yang ditemui secara tidak disengaja di lokasi penelitian dan telah menggunakan maskapai Citilink minimal satu kali. Jumlah sampel yang diambil sebanyak 150 wisatawan Nusantara. Dalam penelitian ini teknik analisis data kuantitatif yang digunakan adalah, uji instrument, uji asumsi klasik, analisis regresi berganda, koefisien determinasi, dan uji hipotesis.

\section{HASIL DAN PEMBAHASAN}

Hasil uji validitas yang telah dilakukan dengan bantuan olahan SPSS menyatakan bahwa dari 15 indikator dinyatakan valid. Hasil uji reliabilitas menunjukkan bahwa kuesioner penelitian ini dinyatakan reliabel untuk pengambilan data penelitian, dengan nilai Alpha Cronbanch setiap variabel lebih besar dari 0,6.

Hasil uji asumsi klasik dalam penelitian ini terdapat tiga uji normalitas, uji multikolineritas, dan uji heteroskedastisitas. Hasil uji normalitas menyatakan bahwa variabel-variabel data pada penelitian ini dinyatakan normal dikarenakan nilai Sig atau Asymp. Sig. (2-tailed) pada uji KolmogorovSmirnov sebesar 0,206 dimana lebih besar dari 0,05 . Hasil uji multikolineritas menyatakan bahwa model regresi penelitian ini tidak terjadinya multikolinieritas dimana nilai VIF sebesar 2,019 dibawah nilai 10 dan nilai tolerance value sebesar 0,495 diatas 0,1. Hasil uji heteroskedastisitas menyatakan bahwa masing-masing variabel tidak adanya gejala heteroskedastisitas nilai signifikansi dari masing-masing variabel $\geq 0,05$ dengan menggunakan uji Glesjer.

Analisis regresi berganda digunakan untuk mengetahui pengaruh harga dan citra merek terhadap keputusan pembelian. Adapun persamaan regresi berganda pada penelitian ini adalah $\mathrm{Y}=5,957+0,462+0,538+\mathrm{e}$, dengan demikian dapat dijelaskan bahwa harga berpengaruh terhadap keputusan pembelian sebesar 0,462 dan citra merek berpengaruh terhadap keputusan pembelian sebesar 0,538.

Hasil analisis koefisien determinasi dalam penelitian ini menyatakan besar pengaruh harga dan citra merek terhadap keputusan pembelian sebesar $60,6 \%$. Dimana 
nilai Adjusted $R$ Square sebesar 0,606 bila dijadikan persentase menjadi $60,6 \%$. Sisa persentase sebesar $39,4 \%$ menunjukan pengaruh dari variabel lain yang tidak dipaparkan pada penelitian ini.

Uji hipotesis dalam penelitian ini terdapat dua uji yaitu uji $t$ dan uji f. Hasil uji $t$ pertama yaitu pengaruh harga terhadap keputusan pembelian. Terlihat bahwa nilai $t_{\text {hitung }}$ sebesar 4,805 $>$ dari $t_{\text {tabel }}$ sebesar 1,655, dengan demikian dari hasil tersebut dapat disimpulkan hipotesis $\mathrm{H}_{1}$ diterima yang berarti variabel harga memiliki pengaruh yang positif dan signifikan terhadap keputusan pembelian tiket maskapai Citilink oleh wisatawan dan layak dijadikan penentu dari variabel keputusan pembelian. Hasil uji t kedua yaitu pengaruh citra merek terhadap keputusan pembelian menunjukan bahwa $t_{\text {hitung }}$ sebesar $6,750>$ dari $t_{\text {tabel }}$ sebesar 1,655. Dari hasil tersebut dapat disimpulkan hipotesis $\mathrm{H}_{1}$ diterima yang berarti variabel citra merek memiliki pengaruh yang positif dan signifikan terhadap keputusan pembelian tiket maskapai Citilink oleh wisatawan dan layak dijadikan penentu dari variabel keputusan pembelian.

Hasil uji $\mathrm{F}$ menunjukkan kedua variabel secara bersamaan berpengaruh terhadap keputusan pembelian yang menunjukan bahwa $\mathrm{f}_{\text {hitung }}$ sebesar 115,605 > dari $\mathrm{f}_{\text {tabel }}$ sebesar 3,06. Dari hasil tersebut dapat disimpulkan hipotesis $\mathrm{H}_{1}$ diterima yang berarti variable harga dan citra merek memiliki pengaruh secara simultan terhadap keputusan pembelian tiket maskapai Citilink oleh wisatawan.

Maskapai Citilink merupakan maskapai penerbangan dibawah manajemen Garuda Indonesia yang berdiri pada tahun 2001. Adapaun karakteristik wisatawan dibagai menjadi karakteristik berdasarkan jenis kelamin, usia, kota domisili, pekerjaan, tujuan, frekuensi penggunaan, dan media informasi (Pitana \& Gayatri 2005). Berdasarkan jenis kelamin yang mendominasi adalah jenis kelamin perempuan sebesar 87 orang dengan persentase $58 \%$. Berdasarkan kelompok usia yang mendominasi adalah 20-30 tahun sebesar 99 orang dengan persentase $66 \%$. Berdasarkan kota domisili yang mendominasi adalah Denpasar sebesar 30 orang dengan persentase $20 \%$. Berdasarkan pekerjaan yang mendominasi adalah mahasiswa/i sebesar 81 orang dengan persentase $54 \%$. Berdasarkan tujuan mendominasi dengan tujuan berlibur sebesar 150 orang dengan persentase $100 \%$.
Berdasarkan frekuensi penggunaan yang mendominasi adalah 1-3 kali penggunaan sebesar 77 orang dengan persentase $51,3 \%$. Dan berdasarkan sumber informasi yang mendominasi adalah website sebesar 57 orang dengan persentase $34,7 \%$.

Berdasarkan hasil analisis regresi berganda yang dimana didapat suatu persamaan $\mathrm{Y}=5,957+0,462+0,538+\mathrm{e}$, yang menyatakan bahwa variabel harga dan citra merek memiliki pengaruh terhadap keputusan pembelian secara positif. Semakin bersar pengearuh variabel $\mathrm{x}$ semakin besar pula keputusan pembelian wisatawan terhadap pembelian tiket maskapai Citilink. Didukung juga dengan hasil uji hipotesis yaitu uji $t$ dan uji f.

Harga $(x l)$ berpengaruh positif dan signifikan terhadap keputusan pembelian (y) tiket maskapai Citilink, dengan kata lain semakin baik variabel harga yang ditawarkan oleh maskapai Citilink semakin besar pula pengaruh terhadap keputusan pembelian wisatawan dalam pembelian tiket.

Harga menurut Herman, et. al. (2007) terbagi menjadi tiga kategori yang sangat sesuai dengan maskapai Citilink, yaitu keterjangkauan harga, diskon/potongan harga dan cara pembayaran. Dari ketiga kategori tersebut maskapai Citilink telah memaksimalkannya. Terlihat dari harga yang ditawarkan kepada wisatawan yang dapat dijangkau oleh setiap kalangan dan tanpa melupakan pelayanan yang diberikan oleh maskapai Citilink. Diskon/potongan harga telah dilakukan untuk menarik wisatawan dalam pembelian tiket. Cara pembayaran yang diberikan oleh maskapai Citilink tidak hanya menggunakan offline, melainkan maskapai ini menawarkan cara pembayaran menggunakan online yanitu dengan katur ATM, kartu kredit, SMS banking dan online banking. Itu semua dilakukan untuk menarik wisatawan agar yakin semakin yakin untuk memutuskan keputusannya dalam mmbeli tiket maskapai.

Citra merek (x2) berpengaruh positif dan signifikan terhadap keputusan pembelian (y) tiket maskapai Citilink, dengan kata lain semakin baik citra merek maskapai Citilink semakin besar pula pengaruh terhadap wisatawan dalam mengambil keputusan dalam pembelian tiket.

Untuk mengukur citra merek dapat dialakukan dengan aspek kekuatan, keunikan, 
dan berkesan (Keller, 2008). Citra merek dilihat dari segi nama, logo, warna dan slogan.

Harga (x1) dan citra merek (x2) secara simultan berpengaruh positif dan signifikan terhadap keputusan pembelian (y) tiket maskapai Citilink. Harga dan citra merek merupakan dua faktor yang dapat mempengaruhi wisatawan dalam keputusan pembelian tiket. Dikarenakan kedua faktor ini merupakan hal yang pertama kali diperhatikan oleh wisatawan. Harga dan citra merek memiliki hubungan satu sama lainnya. Maskapai Citilink merupakan maskapai yang bertarif rendah atau biasa disebut dengan $L C C$, dengan pernyataan tersebut berpengaruh pula terhadap citra merek maskapai ini.

\section{SIMPULAN DAN SARAN Simpulan}

Berdasarkan hasil analisis regresi berganda menyatakan bahwa harga den citra merek memiliki pengaruh positif terhadap keputusan pembelian. Diperkuat dengan hasil uji koefisien detereminasi, dimana harga dan citra merek meiliki pengaruh sebesar $60,6 \%$ terhadap keputusan pembelian. Didukung pula dengan hasil uji hipotesis yaitu uji t dan uji f.

Hasil uji t menyatakan bahwa harga dan citra merek secara parsial memiliki pengaruh positif dan signifikan terhadap keputusan pembelian, dengan nilai $t_{\text {tabel }}$ lebih besar dari nilai $t_{\text {hitung }}$ dan nilai signifikansi lebih kecil dari 0,05 . Sedangkan hasil uji f menyatakan bahwa harga dan citra merek secara simultan memiliki pengaruh positif dan signifikan terhadap keputusan pembelian.

\section{Saran}

Dari segi harga yang ditawarkan kepada wisatawan diharapkan selalu melihat dari segi pelayanan yang diberikan dan dapat dijangkau oleh setiap kalangan. Promo - promo harga yang ditawarkan dapat lebih menarik lagi agar dapat menarik wisatawan. Dari segi citra merek, selalu menjaga nama baik perusahaan karena dapat mempengaruhi citra merek maskapai. Diharapkan kedepannya maskapai Citilink dapat memperbanyak jumlah jam terbang dan rute penerbangan, agar dapat memperluas pangsa pasar dan memperbanyak jumlah pembelian tiket.

\section{DAFTAR PUSTAKA}

Anonim, 2016. Jumlah Penumpang Maskapai Citilink 2011-2015. www.tempo.co. Diakses 30 Oktober 2016.

Anonim, 2016. Gambaran Umum dan Penghargaan Maskapai Citilink. www.citilink.co.id. Diakses 9 April 2016.

Hermann, et, al. 2007. The social influence of brand community: evidence from European car clubs. Journal of Marketing, Vol. 69.

Keller, Kevin Lane. 2008. Strategic Brand Management : Building, Measuring and Management Brand Equity 3rd Edition. Upper Saddle River, NJ: Prentince Hall.

Kotler dan Amstrong. 2006. Prinsip-prinsip Pemasaran. Edisi Ke 12. Jakarta: Erlangga.

Pitana, Gede dan Putu Gayatri. 2005. Sosiologi Pariwisata. Yogyakarta : Andi.

Sangadji dan Sopiah. 2013. Perilaku Konsumen. Yogyakarta: Andi.

Sugiyono. 2014. Metode Penelitian Bisnis. Bandung: Alfabeta.

Sujarweni, 2015. SPPS Untuk Penelitian. Yogyakarta: Pustaka Baru Press. 